\title{
ROLA ŚWIADCZEŃ RODZINNYCH W POLSKIEJ POLITYCE RODZINNEJ
}

\section{Streszczenie}

Cel - Głównym celem opracowania była próba scharakteryzowania polskiej polityki rodzinnej w kontekście stosowania tradycyjnych instrumentów wsparcia rodzin, jakimi są bezpośrednie świadczenia pieniężne. Dodatkowym celem było wskazanie konsekwencji budżetowych, jakie pociąga za sobą stosowanie tych instrumentów.

Metodyka badania - W artykule zastosowano następujące metody badawcze: analizę literatury przedmiotu i aktów prawnych, analizę danych statystycznych oraz analizę porównawczą. Charakterystyki instrumentów polskiej polityki rodzinnej dokonano na podstawie analizy aktów prawnych regulujących funkcjonowanie poszczególnych instrumentów oraz analizy opracowań przygotowywanych przez Ministerstwo Rodziny, Pracy i Polityki Społecznej. Badaniami objęto lata 2004-2018.

Wynik - Przeprowadzone badanie pozwoliło na potwierdzenie hipotezy mówiącej o tym, że brak kryterium dochodowego upoważniającego do otrzymania świadczeń pieniężnych w ramach realizowanej polityki rodzinnej powoduje, że pomoc finansowa często trafia także do osób o wysokich dochodach. Potwierdzony został również istotny wpływ braku tego kryterium na wzrost wydatków publicznych związanych z polityką rodzinną.

Oryginalność/wartość - Badanie przeprowadzone w artykule pozwala na poszerzenie wiedzy z zakresu instrumentów bezpośredniego wsparcia rodzin w ramach realizowanej w Polsce polityki rodzinnej oraz ukazanie konsekwencji budżetowych tej polityki.

Słowa kluczowe: polityka rodzinna, świadczenia rodzinne, polityka fiskalna

\section{THE ROLE OF FAMILY BENEFITS IN FAMILY POLICY IN POLAND}

\section{Summary}

Goal - The main objective of the study was an attempt to describe family policy in Poland in the context of applying traditional family support instruments such as direct cash benefits. An additional goal was to indicate the budgetary consequences of using these instruments.

Research methodology - The following research methods were used in the article: analysis of the literature on the subject and legal acts, analysis of statistical data and comparative analysis. The study uses statistical data from reports of the Ministry of Finance and the Ministry of Family, Labor and Social Policy. The time frame of the study covers the years 2004-2018.

Score - The conducted research allowed to confirm the hypothesis which says that the lack of income criterion authorizing to receive cash benefits as part of the family policy being implemented 
means that financial assistance is often also given to people with high incomes. The significant impact of the absence of this criterion on the increase in public expenditure related to family policy was also confirmed.

Originality /value - Research conducted in the article allows to broaden the knowledge of the instruments of direct support for families as part of the family policy implemented in Poland and to show the budget consequences of this policy.

Keywords: family policy, family benefits, fiscal policy

DOI: 10.15290/wpewbmn4.2020.08

\section{Wprowadzenie}

Rodzina, określana jako podstawowa komórka społeczna, jest naturalnym środowiskiem dla narodzin i rozwoju człowieka ${ }^{1}$. Poprzez pełnienie swoich funkcji wywiera wpływ na kształtowanie się struktury społecznej danego kraju. Z jednej strony zaspokaja potrzeby swoich członków, będących również członkami społeczeństwa, przez co wpływa na jego funkcjonowanie. $Z$ drugiej strony jest uzależniona od zewnętrznych uwarunkowań, w których funkcjonuje, takich jak: sytuacja społeczno-ekonomiczna, polityczna czy kulturowa. Mogą one pozytywnie lub negatywnie wpływać na funkcjonowanie rodziny i na realizowane przez nią funkcje².

Istotną rolę w zakresie tworzenia warunków dla rozwoju i funkcjonowania rodzin odgrywa państwo, a w szczególności prowadzona przez władze polityka rodzin$\mathrm{na}^{3}$. Stanowi ona długofalowy system celów i rozwiązań prawnych ukierunkowanych na wsparcie rodzin ${ }^{4}$. Polityka rodzinna określa zakres działań rządu, które mają na celu oddziaływanie na sytuację rodzin, a zwłaszcza rodzin z dziećmi ${ }^{5}$. Jednym z podstawowych założeń tej polityki jest kreowanie warunków sprzyjających prawidłowemu funkcjonowaniu rodzin poprzez podejmowanie działań, które doprowadzą do poprawy warunków ich życia, co w dłuższej perspektywie ma przyczyniać się do rozwoju społeczeństwa i osiągnięcia pożądanych zmian jego struktury ${ }^{6}$.

Polityka rodzinna, ze względu na wyzwania przed nią stojące, jest jedną z ważniejszych polityk państwa. Źle zaprojektowana może mieć negatywne skutki

1 B.M. Kałdon, Rodzina jako instytucja społeczna w ujęciu interdyscyplinarnym, „Forum Pedagogiczne UKSW" 2011, nr 1, s. 230.

2 GUS, Działania prorodzinne w latach 2010-2015, Kraków, 2016, s. 25.

3 A. Durasiewicz, Kierunki rozwoju polityki rodzinnej $w$ Polsce - dylemat społeczny zachodzacych zmian i wyzwań na przyszłość, [w:] Polityka społeczna wobec wyzwań i zmian zachodzacych we współczesnym świecie, M. Kubiak (red.), Uniwersytet Gdański, Gdańsk 2014, s. 102.

4 A. Durasiewicz, Instrumenty polityki rodzinnej państwa, [w:] Biuletyn Informacyjny Wiadomości Społeczne Nr 1/2009, K. Głąbicka (red.), Polskie Towarzystwo Polityki Społecznej, Warszawa 2009, s. 57.

${ }_{5}$ Ibidem, cyt. za S.B. Kamerman, Rodzina: problemy teorii i polityki, [w:] O polityce rodzinnej: definicje, zasady, praktyka, „Materiały z Zagranicy”, Instytut Pracy i Spraw Socjalnych, Warszawa 1994, s. 12.

${ }_{6}$ B. Balcerzak-Paradowska, Rodzina i polityka rodzinna na przełomie wieków, Instytut Pracy i Spraw Socjalnych, Warszawa, 2004; A. Durasiewicz, Instrumenty..., s. 57-58, cyt. za: A. Kurzynowski, Problemy rodziny w polityce społecznej, Ośrodek Badań Społecznych, Warszawa 1991, s. 96. 
dla rozwoju gospodarki i społeczeństwa. Główne problemy, z którymi zmaga się polityka rodzinna, to niski poziom dzietności oraz problemy materialne rodzin, w szczególności rodzin wielodzietnych ${ }^{7}$.W dłuższym okresie spadek poziomu urodzeń może przyczyniać się do zmniejszania udziału ludności w wieku produkcyjnym w strukturze populacji, co z kolei jest zagrożeniem dla stabilności finansów publicznych, rynku pracy czy też systemu emerytalnego ${ }^{8}$. Niski poziom dzietności wskazywany jest również jako jeden z głównych czynników demograficznych, który destabilizuje rozwój społeczno-gospodarczy poprzez hamowanie ilościowego rozwoju podaży pracy oraz jest powodem starzenia się zasobów pracy ${ }^{9}$. Biorąc pod uwagę sytuację materialną rodzin, należy zwrócić uwagę, że niedostateczne dochody mogą przyczyniać się do ograniczenia możliwości rozwoju danej jednostki. W konsekwencji może to mieć wpływ na rozwój całego kapitału ludzkiego, społeczeństwa i ostatecznie gospodarki ${ }^{10}$.

Jednym z głównych instrumentów polityki rodzinnej są bezpośrednie świadczenia pieniężne skierowane do rodzin. $W$ ostatnich latach w Polsce wprowadzono kilka nowych świadczeń pieniężnych na rzecz rodzin, nad którymi toczy się ożywiona dyskusja dotycząca celowości ich wprowadzenia oraz konsekwencji budżetowych, jakie ze sobą niosą ${ }^{11}$. W związku z powyższym, głównym celem opracowania jest próba scharakteryzowania polskiej polityki rodzinnej w kontekście stosowania tradycyjnych instrumentów wsparcia rodzin, jakimi są bezpośrednie świadczenia pieniężne. Dodatkowym celem jest wskazanie skutków budżetowych związanych z ich stosowaniem. W badaniu podjęto próbę weryfikacji następującej hipotezy badawczej: „Brak kryterium dochodowego upoważniającego do otrzymania świadczeń pieniężnych $w$ ramach realizowanej polityki rodzinnej powoduje, że pomoc finansowa często trafia także do osób o wysokich dochodach. Jednocześnie ma to wpływ na wzrost wydatków publicznych".

$\mathrm{W}$ artykule zastosowano następujące metody badawcze: analizę literatury przedmiotu i aktów prawnych, analizę danych statystycznych oraz analizę porównawczą. Charakterystyki instrumentów polskiej polityki rodzinnej dokonano na podstawie analizy aktów prawnych regulujących funkcjonowanie poszczególnych instrumentów oraz analizy opracowań przygotowywanych przez Ministerstwo Rodziny, Pracy i Polityki Społecznej (MRPiPS). Badaniami objęto lata 2004-2018 ${ }^{12}$.

\footnotetext{
7 J. Szczepaniak-Sienniak, Polityka rodzinna państwa we współczesnej Polsce, „Społeczeństwo i Ekonomia", 2015, nr 2(4), s. 103.

8 W. Adema, N. Ali, O. Thévenon, Changes in Family Policies and Outcomes: Is there Convergence?, OECD Social, Employment and Migration Working Papers, 2014, no. 157, OECD Publishing, Paris, http://dx.doi.org/10.1787/5jz13wllxgzt-en [dostęp: 26.06.2019].

9 J. Szczepaniak-Sienniak, Polityka..., s. 103.

${ }^{10}$ Ibidem.

${ }^{11}$ W Polsce w ostatnich latach wprowadzono m.in. program „Rodzina 500 plus” (2016), czy program „Dobry start” (2018).

${ }^{12}$ Ze względu na to, że nowy system świadczeń rodzinnych nie funkcjonował przez cały 2004 rok pominięto go przy analizie danych. Ze względu na brak pełnych danych statystycznych pominięty został również rok 2018.
} 


\section{Podział i funkcje instrumentów polityki rodzinnej}

Instrumenty wykorzystywane $\mathrm{w}$ ramach polityki rodzinnej można podzielić na dwie grupy. Przyjmując za kryterium ich podziału związek z dochodem rozporządzalnym beneficjentów, wyodrębnić można grupę instrumentów tradycyjnych (dochodowych), które bezpośrednio przyczyniają się do wzrostu dochodu rozporządzalnego beneficjentów oraz grupę instrumentów niedochodowych, które bezpośrednio nie przyczyniają się do podnoszenia tych dochodów. W ramach instrumentów dochodowych, biorąc pod uwagę sposób wydatkowania środków publicznych, wyodrębnić można dwie podgrupy, tj.: instrumenty bezpośrednie w postaci świadczeń pieniężnych oraz instrumenty pośrednie w postaci różnego rodzaju preferencji podatkowych. Do kategorii niedochodowych instrumentów zalicza się m.in. korzystne regulacje prawne (np. urlopy macierzyńskie) czy świadczenia w naturze (np. opieka nad dziećmi w placówkach publicznych) ${ }^{13}$.

Świadczenia pieniężne jako instrument polityki rodzinnej pełnią następujące funkcje ${ }^{14}$ :

- dochodową - świadczenie stanowi źródło dochodów rodziny;

- kompensacyjną - polegającą na rekompensacie części ponoszonych wydatków związanych z posiadaniem dzieci;

- redystrybucyjną - która polega na wtórnym podziale dochodów poprzez transfer środków od jednych grup społecznych do innych, w tym przypadku do rodzin z dziećmi;

- $\quad$ egalitaryzującą - która polega na zmniejszaniu różnic w poziomie życia poszczególnych grup społecznych (rodzin);

- $\quad$ stymulującą - która polega na oddziaływaniu na określone postawy i zachowania w społeczeństwie, kierując spożyciem zgodnie z kierunkiem uznanym przez społeczeństwo za ważny.

Wyżej wymienione funkcje mogą być realizowane jednocześnie, np. zasiłek rodzinny, którego przyznanie i wysokość jest uzależnione od liczby dzieci, ich wieku i poziomu dochodów rodziny, spełnia co najmniej trzy funkcje, tj. dochodową, redystrybucyjną oraz egalitaryzującą. Należy podkreślić, że w zależności od etapu rozwoju polityki rodzinnej oraz od jej celów w danym okresie, rodzaje przysługujących świadczeń oraz zasady ich przyznawania kształtują się inaczej ${ }^{15}$. Można to

\footnotetext{
${ }_{13}$ Zaprezentowany podział instrumentów polityki rodzinnej przedstawiony w oparciu o: S. Billingsley, T. Ferrarini, Family Policy and Fertility Intentions in 21 European Countries, „Journal of Marriage and Family", 2014, vol. 76; H. Lohmann, F.H. Peter, T. Rostgaard, K. Spiess, Towards a Framework for Assessing Family Policies in the EU, OECD Social, Employment and Migration Working Papers, 2009, no. 88, OECD Publishing, Paris, http://dx.doi.org/10.1787/223883627348 [dostęp: 26.06.2019]; OECD, The balance of family policy tools - benefit packages, spending by age and families with young children, in Doing Better for Families, OECD Publishing, 2011, Paris, https://doi.org/10.1787/9789264098732-4-en/ [dostęp: 26.06.2019].

${ }^{14}$ A. Durasiewicz, Instrumenty..., s. 59, cyt. za: J. Auleytner, K. Głąbicka, Polityka społeczna pomiędzy opiekuńczością a pomocniczością, WSP TWP, Warszawa 2000, s. 178.

${ }^{15}$ Ibidem, s. 59.
} 
także zaobserwować w polskiej polityce rodzinnej, zwłaszcza po wstąpieniu do Unii Europejskiej.

\section{Świadczenia rodzinne w Polsce w latach 2004-2018}

W 2004 roku w Polsce został wprowadzony nowy system świadczeń rodzinnych, który scalił i uporządkował dotychczas funkcjonujące rozwiązania w zakresie wspierania rodzin z dziećmi. Wprowadzony system jest systemem zaopatrzeniowym, finansowanym ze środków budżetu państwa. Opiera się on na zasadzie pomocniczości oznaczającej, że do utrzymania dzieci zobowiązani są rodzice, a dopiero w przypadku, gdy ich środki nie są wystarczające, przysługuje im wsparcie ze strony państwa ${ }^{16}$. Podstawę prawną obowiązującego do dzisiaj systemu stanowi ustawa z dnia 28 listopada 2003 roku o świadczeniach rodzinnych ${ }^{17}$. Uzupełnieniem systemu świadczeń rodzinnych są świadczenia przyznawane na bazie odrębnych ustaw i rozporządzeń ${ }^{18}$.

W polskiej polityce rodzinnej okres 2004-2018 można podzielić na dwa etapy. Pierwszy to lata 2004-2012. W tym okresie funkcjonowało pięć kategorii świadczeń bezpośrednich wprowadzonych w 2004 roku oraz jedno funkcjonujące od 2006 roku (tabela 1). W tym okresie pomoc skierowana była w głównej mierze do rodzin najuboższych. Wskazuje na to konieczność spełnienia kryterium dochodowego w celu uzyskania większości świadczeń. Jedynie w zakresie wsparcia osób niepełnosprawnych oraz przy wypłacie jednorazowej zapomogi z tytułu urodzenia się dziecka nie było konieczności spełnienia tego kryterium ${ }^{19}$.

W latach 2013-2018 nastąpiła ekspansja polityki rodzinnej w zakresie wsparcia rodzin poprzez transfery bezpośrednie. W tym okresie wprowadzono cztery nowe świadczenia funkcjonujące do dzisiaj oraz świadczenie pielęgnacyjne wprowadzone w 2013 roku, które funkcjonowało jedynie przez dwa lata. Należy również zwrócić uwagę, że w tym okresie wprowadzono istotną zmianę w zakresie wypłaty jednorazowej zapomogi z tytułu urodzenia się dziecka, która od 1 stycznia 2013 roku została uzależniona od spełnienia kryterium dochodowego ${ }^{20}$.

W latach 2005-2015 poziom wydatków budżetu państwa na świadczenia rodzinne był w miarę stabilny i wahał się w przedziale od 7,80 mld zł w 2005 roku do 9,14 mld zł w 2012 roku (wykres 1). W 2015 roku poziom wydatków na transfery do rodzin wyniósł 8,95 mld zł i był o około 15\% wyższy niż w 2005 roku. Udział

\footnotetext{
${ }^{16}$ Informacja o realizacji świadczeń rodzinnych $w 2016$ r., MRPiPS, Warszawa 2017, s. 4.

17 Ustawa z 28 listopada 2003 r. o świadczeniach rodzinnych (Dz.U. z 2018 r. poz. 2220).

${ }^{18}$ Są to: Ustawa z dnia 7 września 2007 r. o pomocy osobom uprawnionym do alimentów (Dz.U. z 2019 r. poz. 670); Ustawa z dnia 11 lutego 2016 r. o pomocy państwa w wychowywaniu dzieci (Dz.U. z 2018 r. poz. 2134); Rozporządzenie Rady Ministrów z dnia 30 maja 2018 r. w sprawie szczegółowych warunków realizacji rządowego programu „Dobry start” (Dz.U. z 2018 poz. 1061).

${ }_{19}$ Przeglą systemów wsparcia rodzin, MRPiPS, Warszawa 2017; Informacja o realizacji ustawy o postępowaniu wobec dłużników alimentacyjnych oraz zaliczce alimentacyjnej, MRPiPS, Warszawa 2006.

${ }^{20}$ MRPiPS, Przegląd...
} 
wydatków na wypłatę świadczeń uzależnionych od spełnienia kryterium dochodowego spadł w tym okresie z około 81\% w 2005 roku do około 58\% w 2015 roku. Głównym powodem spadku tego udziału było zmniejszenie wydatków na wypłatę zasiłków rodzinnych wraz z dodatkami oraz wzrost nakładów na wsparcie rodzin z osobami niepełnosprawnymi na utrzymaniu. Przyczyną zmniejszenia wydatków na zasiłki rodzinne wraz z dodatkami był fakt, iż kryterium dochodowe w tym okresie nie ulegało zmianie. W wyniku tego, liczba korzystających z tych świadczeń zmniejszyła się z około 5,2 mln w 2005 roku do około 2,0 mln w 2015 roku $^{21}$.

Tabela 1.

Charakterystyka świadczeń pieniężnych na rzecz rodzin w Polsce w latach 2004-2018

\begin{tabular}{|c|c|}
\hline $\begin{array}{l}\text { Rodzaj } \\
\text { świadczenia }\end{array}$ & Cel i aktualne warunki uzyskania \\
\hline $\begin{array}{l}\text { Zasiłek rodzinny } \\
\text { (2004) }\end{array}$ & $\begin{array}{l}\text { Cel: Częściowe pokrycie wydatków związanych z wychowywaniem dziecka. } \\
\text { Zasiłek przysługuje rodzicom, jednemu z rodziców, opiekunowi prawnemu dziecka, } \\
\text { opiekunowi faktycznemu dziecka lub osobie uczącej się po spełnieniu kryterium do- } \\
\text { chodowego. Od } 1 \text { listopada } 2018 \text { r. kryterium dochodowe wynosi } 674 \text { zł netto na } \\
\text { osobę w rodzinie lub } 764 \text { zł netto jeżeli członkiem rodziny jest dziecko niepełno- } \\
\text { sprawne. Wysokość zasiłku rodzinnego wynosi miesięcznie } 95 \text { zł na dziecko w wieku } \\
\text { do ukończenia } 5 \text {. roku życia. } 124 \text { zł na dziecko powyżej } 5 \text {. roku życia do ukończenia } \\
\text { 18. roku życia. } 135 \text { zł na dziecko w wieku powyżej 18. roku życia do ukończenia } 24 \text {. } \\
\text { roku życia. } \\
\text { Wydatki budżetu państwa w } 2017 \text { r.: około } 2,89 \text { mld zł. }\end{array}$ \\
\hline $\begin{array}{l}\text { Dodatki do za- } \\
\text { siłku rodzinnego } \\
\text { (2004) }\end{array}$ & $\begin{array}{l}\text { Cel: Częściowe pokrycie wydatków związanych z wychowywaniem dziecka. } \\
\text { Warunkiem niezbędnym do otrzymania dodatku do zasiłku rodzinnego jest otrzyma- } \\
\text { nie zasiłku, czyli spełnienie kryterium dochodowego. W } 2019 \text { r. dodatki do zasiłku } \\
\text { rodzinnego można otrzymać z następujących tytułów: } \\
\text { - urodzenia dziecka (1000 zł jednorazowo), } \\
\text { - opieki nad dzieckiem w okresie korzystania z urlopu wychowawczego (400 zł mie- } \\
\text { sięcznie), } \\
\text { - samotnego wychowywania dziecka (193 zł miesięcznie na dziecko, nie więcej niż } \\
386 \text { zł na wszystkie dzieci, w przypadku dzieci niepełnosprawnych kwotę zwiększa } \\
\text { się odpowiednio o } 80 \text { zł lub maksymalnie } 160 \text { zł), } \\
\text { - wychowywania dziecka w rodzinie wielodzietnej ( } 95 \text { zł miesięcznie na trzecie i ko- } \\
\text { lejne dziecko), } \\
\text { - kształcenia i rehabilitacji dziecka niepełnosprawnego ( } 90 \text { zł miesięcznie na dziecko } \\
\text { w wieku do ukończenia 5. roku życia lub } 110 \text { zł na dziecko od 5. roku życia do } 24 . \\
\text { roku życia) } \\
\text { - rozpoczęcia roku szkolnego (100 zł jednorazowo), } \\
\text { - podjęcia przez dziecko nauki w szkole poza miejscem zamieszkania (113 zł mie- } \\
\text { sięcznie na stancję/internat lub } 69 \text { zł miesięcznie na dojazdy do szkoły). } \\
\text { Wydatki budżetu państwa w } 2017 \text { r.: około } 1,52 \text { mld zł. }\end{array}$ \\
\hline $\begin{array}{l}\text { Zasiłek } \\
\text { gnacyj }\end{array}$ & $\begin{array}{l}\text { Cel: Częściowe pokrycie wydatków wynikających z konieczności zapewnienia pomo- } \\
\text { cy i opieki innej osoby w związku z niezdolnością do samodzielnej egzystencji. } \\
\text { Zasiłek przysługuje niepełnosprawnemu dziecku, osobie niepełnosprawnej w wieku } \\
\text { powyżej 16. roku życia, jeżeli posiada znaczny stopień niepełnosprawności oraz oso- } \\
\text { bie, która ukończyła } 75 \text { lat. Zasiłek przysługuje bez względu na osiągany dochód. } \\
\text { Wysokość zasiłku w okresie od } 1 \text { listopada } 2018 \text { r. do } 31 \text { października } 2019 \text { r. wynosi } \\
184,42 \text { zł miesięcznie. Od dnia } 1 \text { listopada } 2019 \text { r. wysokość zasiłku wyniesie } 215,84 \\
\text { zł. } \\
\text { Wydatki budżetu państwa w } 2017 \text { r.: około } 1,68 \text { mld zł. }\end{array}$ \\
\hline
\end{tabular}

${ }^{21}$ Ibidem, s. 51. 


\section{Rodzaj świadczenia \\ Cel i aktualne warunki uzyskania}

Świadczenie pielęgnacyjne (2004)

Cel: Częściowe zrekompensowanie opiekunowi braku aktywności zawodowej wynikającej z konieczności opieki nad osobą niepełnosprawną.

Świadczenie przysługuje osobom, które rezygnują z zatrudnienia lub go nie podejmują w celu sprawowania opieki nad niepełnosprawnym dzieckiem, którego niepełnosprawność powstała przed ukończeniem 18. roku życia lub 25. roku życia, jeśli niepełnosprawność powstała w trakcie nauki w szkole lub szkole wyższej. Świadczenie przysługuje bez względu na osiągany dochód. Kwota świadczenia w 2019 r. wynosi 1583 zł miesięcznie. Od 1 stycznia 2017 r. wysokość świadczenia podlega corocznej waloryzacji o wskaźnik, którym jest procentowy wzrost minimalnego wynagrodzenia za pracę w roku poprzednim.

Wydatki budżetu państwa w 2017 r.: około 2,07 mld zł.

Świadczenia $\quad$ Cel: Wspieranie osób uprawnionych do alimentów środkami finansowymi z budżetu z funduszu alimentacyjnego (2004)

\section{państwa.}

Świadczenie przysługuje osobom uprawnionym, w przypadku bezskutecznej egzekucji prowadzonej wobec dłużników alimentacyjnych. W celu otrzymania świadczenia z funduszu musi zostać spełnione kryterium dochodowe wynoszące 725 zł netto na osobę w rodzinie. Wysokość świadczenia wypłaconego z funduszu nie może przekraczać 500 zł miesięcznie na osobę.

Wydatki budżetu państwa w 2017 r.: około 1,38 mld zł.

\section{Jednorazowa} zapomoga z tytułu urodzenia się dziecka (2006)

Dodatek do świadczenia pielęgnacyjnego (2013-2014)

\section{Cel: Częściowe pokrycie wydatków związanych z wychowywaniem dziecka.}

Zapomoga z tytułu urodzenia się dziecka, tzw. „becikowe”, przysługuje w 2019 r. rodzicom dziecka lub opiekunowi prawnemu, jeżeli dochód rodziny w przeliczeniu na jedną osobę nie przekracza kwoty 1922 zł. Wydatki budżetu państwa w 2017 r.: około 0,37 mld zł.

Cel: Udzielenie dodatkowej pomocy finansowej osobom uprawnionym do świadczenia pielęgnacyjnego.

Podstawą udzielanej pomocy w tym okresie był rządowy program wspierania osób otrzymujących świadczenie pielęgnacyjne. W początkowym okresie wysokość dodatku wynosiła 100 zł miesięcznie, w kolejnym okresie wzrosła do 200 zł miesięcznie. Dodatek do świadczenia pielęgnacyjnego został zlikwidowany w momencie, kiedy znacznie zwiększono wysokość świadczenia pielęgnacyjnego. Dodatek przysługiwał niezależnie od poziomu uzyskiwanych dochodów rodziny.

Wydatki budżetu państwa w latach 2013-2014 r.: w sumie około 0,06 mld zł.
Specjalny zasitek opiekuńczy (2013)

Cel: Częściowe zrekompensowanie opiekunowi braku aktywności zawodowej wynikającej z konieczności opieki nad osobą niepełnosprawną.

Zasiłek przysługuje osobom, które rezygnują z zatrudnienia lub go nie podejmują w celu sprawowania opieki nad niepełnosprawnym członkiem rodziny, bez względu na wiek powstania niepełnosprawności. W praktyce zasiłek ten przysługuje osobom, które nie spełniają warunków do otrzymania świadczenia pielęgnacyjnego. Zasiłek ten przysługuje po spełnieniu kryterium dochodowego, które wynosi w 2019 r. 764 zł w przeliczeniu na osobę w rodzinie. Kwota świadczenia w 2019 r. wynosi 1583 zł miesięcznie.

Wydatki budżetu państwa w 2017 r.: około 0,27 mld zł.

\section{Świadczenie} rodzicielskie (2016)
Cel: Częściowe pokrycie wydatków związanych z wychowywaniem dziecka.

Świadczenie to przysługuje osobom, które urodziły dziecko, ale nie posiadają prawa do zasiłku macierzyńskiego lub uposażenia macierzyńskiego. Uprawnieni do tego świadczenia są m.in. bezrobotni, studenci oraz osoby wykonujące pracę na podstawie umów cywilnoprawnych. Wysokość świadczenia wynosi 1000 zł miesięcznie przez okres od 52 do 71 tygodni, w zależności od liczby urodzonych jednorazowo dzieci. Świadczenie to przysługuje niezależnie od wysokości osiąganego dochodu. Wydatki budżetu państwa w 2017 r.: około 1,14 mld zł. 


\begin{tabular}{l|l}
\hline $\begin{array}{l}\text { Rodzaj } \\
\text { świadczenia }\end{array}$ & \multicolumn{1}{c}{ Cel i aktualne warunki uzyskania } \\
\hline $\begin{array}{l}\text { Świadczenie } \\
\text { z programu } \\
\text { Rodzina 500 } \\
\text { plus (2016) }\end{array}$ & $\begin{array}{l}\text { Cel: Częściowe pokrycie wydatków związanych z wychowywaniem dziecka, w tym } \\
\text { z opieką nad nim i zaspokojeniem jego potrzeb życiowych. } \\
\text { Świadczenie wychowawcze przysługuje rodzicom, opiekunowi faktycznemu lub opie- } \\
\text { kunowi prawnemu dziecka do dnia ukończenia przez dziecko 18. roku życia. Świad- } \\
\text { czenie przysługuje na każde drugie i kolejne dziecko w rodzinie bez względu na po- } \\
\text { ziom uzyskiwanych dochodów rodziny. Świadczenie przysługuje na pierwsze dziecko, } \\
\text { jeżeli dochód rodziny w przeliczeniu na osobę nie przekracza kwoty 800 zł lub kwoty } \\
\text { 1200 zł jeżeli członkiem rodziny jest dziecko niepełnosprawne. Wysokość świadcze- } \\
\text { nia wynosi 500 zł miesięcznie na każde uprawnione dziecko. }\end{array}$ \\
Wydatki budżetu państwa w 2017 r.: około 22,82 mld zł. \\
\hline $\begin{array}{l}\text { Świadczenie } \\
\text { z programu }\end{array}$ & $\begin{array}{l}\text { Cel: Częściowe pokrycie wydatków związanych z wychowywaniem dziecka. } \\
\text { Świadczenie w wysokości 300 zł prysługuje raz w roku na uczące się dziecko }\end{array}$ \\
(2018) & w związku z rozpoczęciem się roku szkolnego, do ukończenia przez dziecko lub osobę \\
& uczącą się 20. roku życia, a w przypadku osoby niepełnosprawnej 24. roku życia. \\
Świadczenie to przysługuje niezależnie od osiąganych dochodów.
\end{tabular}

Źródło: opracowanie własne na podstawie Ustawy z 28 listopada 2003 r. o świadczeniach rodzinnych (Dz.U. z 2018 r. poz. 2220); Ustawa z dnia 11 lutego 2016 r. o pomocy państwa w wychowywaniu dzieci (Dz.U. z 2018 r. poz. 2134); MRPiPS, Przegląd...; Rozporządzenie Rady Ministrów z dnia 30 maja 2018 r.; MRPiPS, Dobry start, 300 dla ucznia. Podsumowanie w 2018 r., 2019.

Znaczący wzrost wydatków publicznych na świadczenia rodzinne nastąpił w 2016 roku, czyli od momentu wprowadzenia programu Rodzina 500 plus, gdzie kryterium dochodowe dotyczyło przyznania świadczenia wyłącznie na pierwsze dziecko. Należy zauważyć, że wydatki związane z tym programem w 2017 roku wyniosły 22,82 mld zł i były ponad dwukrotnie wyższe niż suma wydatków na wszystkie pozostałe świadczenia, które w tym samym roku wyniosły 11,32 mld zł. W 2017 roku łączne wydatki na transfery pieniężne do rodzin wyniosły 34,15 mld zł i były ponad czterokrotnie wyższe niż ich poziom z 2005 roku i ponad trzyipółkrotnie wyższe niż w 2015 roku.

Charakterystyczne dla świadczeń wprowadzonych po 2013 roku jest to, że nie ma obowiązku spełnienia kryterium dochodowego w celu ich uzyskania (za wyjątkiem specjalnego zasiłku opiekuńczego). Konsekwencją braku wprowadzenia tego kryterium w poszczególnych świadczeniach jest to, że pomoc trafiła do większej grupy osób. Jednocześnie jednak przyczyniło się to do znacznego wzrostu poziomu wydatków budżetowych z tego tytułu. Najbardziej zauważalne jest to od wprowadzenia programu Rodzina 500 plus, w którym kryterium dochodowe dotyczyło wyłącznie pierwszego dziecka. Należy również zauważyć, że od 1 lipca 2019 roku kryterium dochodowe w tym programie zostało całkowicie zniesione, co oznacza, że transfery zasilą budżety domowe jeszcze większej liczby rodzin. Jak wskazują szacunki MRPiPS, koszt wprowadzonych zmian w programie wyniesie około $20,00 \mathrm{mld}$ zł rocznie, czyli tyle co około $60 \%$ wydatków poniesionych na wszystkie transfery w 2017 roku $^{22}$. Biorąc pod uwagę powyższe informacje można szacować,

${ }^{22}$ https://www.portalsamorzadowy.pl/polityka-i-spoleczenstwo/500-plus-na-pierwsze-dziecko-bez-kryterium-dochodowego-ile-bedzie-kosztowac-program,121794.html [dostęp: 26.06.2019]. 
że w 2019 roku udział wydatków na świadczenia pieniężne, w których występuje kryterium dochodowe w sumie wydatków na te transfery wyniesie zaledwie około $10 \%^{23}$.

Wykres 1 .

Wydatki budżetu państwa na świadczenia rodzinne w Polsce w latach 2005-2017

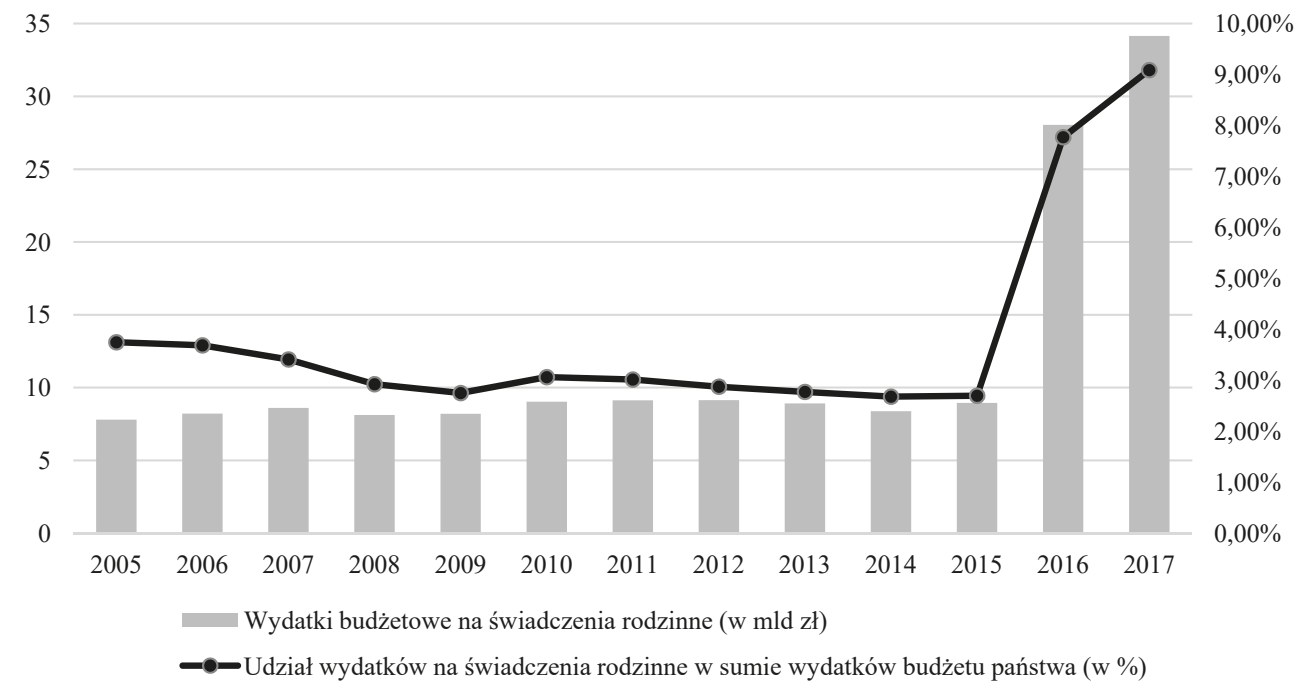

Źródło: opracowanie własne na podstawie MRPiPS, Informacja o realizacji świadczeń rodzinnych..., Warszawa, publikacje z lat 2006-2017; MRPiPS, Przeglad...; MRPiPS, Informacja o realizacji ustawy o postępowaniu wobec dtużników alimentacyjnych oraz zaliczce alimentacyjnej, Warszawa, publikacje z lat 2006-2008; MRPiPS, Informacja o realizacji ustawy o pomocy osobom uprawnionym do alimentów, Warszawa, publikacje z lat 2009-2016; Ministerstwo Finansów, Sprawozdanie z wykonania budżetu państwa, Warszawa, publikacje z lat 2006-2018.

Istotną kwestią z punktu widzenia skuteczności wydatkowania środków publicznych w ramach prowadzonej polityki rodzinnej jest zbadanie, czy pomoc trafia do rodzin, które faktycznie jej potrzebują, czyli rodzin o niskich dochodach. W związku z tym nasuwa się pytanie: „Jaki wpływ ma na to wprowadzenie kryterium dochodowego upoważniającego do otrzymania danego świadczenia?” W tym przypadku istotna jest przede wszystkim analiza skutków zniesienia tego kryterium na pierwsze dziecko w programie Rodzina 500 plus, który z punktu widzenia finansów publicznych jest najdroższym programem w Polsce.

\footnotetext{
${ }^{23}$ Autor dokonał oszacowania przyjmując założenie, że wydatki związane z programem Rodzina 500 plus wzrosną o 20,00 mld zł w stosunku do 2017 r. i wyniosą 42,82 mld zł. Wydatki związane z pozostałymi świadczeniami pozostaną na poziomie z $2017 \mathrm{r}$. W obliczeniach uwzględniono również, program Dobry start, którego szacowany przez MRPiPS koszt w 2019 r. ma wynieść 1,44 mld zł.
} 
Tabela 2.

Całkowite roczne korzyści rodzin z dziećmi w wyniku wprowadzenia programu Rodzina 500 plus według dochodowych grup decylowych (w mld zł)

\begin{tabular}{l|l|l|l|l|l|l|l|l|l|l}
\hline & D1 & D2 & D3 & D4 & D5 & D6 & D7 & D8 & D9 & D10 \\
\hline A & 2,22 & 2,68 & 2,85 & 2,68 & 2,41 & 2,12 & 1,72 & 1,67 & 1,66 & 1,85 \\
\hline B & 0,26 & 0,55 & 1,16 & 1,46 & 1,82 & 2,18 & 2,38 & 2,53 & 2,82 & 3,13 \\
\hline C & 2,48 & 3,23 & 4,00 & 4,13 & 4,24 & 4,31 & 4,10 & 4,21 & 4,48 & 4,98 \\
\hline
\end{tabular}

Legenda:

A - wprowadzenie świadczenia z kryterium dochodowym na pierwsze dziecko

B - upowszechnienie świadczenia (zniesienie kryterium dochodowego na pierwsze dziecko)

C - całkowite korzyści ze świadczenia z uwzględnieniem zniesienia kryterium dochodowego na pierwsze dziecko (A+B)

Źródło: M. Myck, M. Najsztub, M. Oczkowska, K. Trzciński, Pakiet podatkowo-świadczeniowych rozwiązań rządu Zjednoczonej Prawicy, Raport Przedwyborczy CenEA, 12.04.2019, CenEA, s. 18.

Rozkład całkowitych korzyści wynikający z wprowadzenia analizowanego świadczenia z obowiązującym kryterium dochodowym na pierwsze dziecko wskazuje na to, że wsparciem zostały objęte wszystkie rodziny niezależnie od poziomu uzyskiwanych dochodów (tabela 2). Zauważyć można, że większa część środków publicznych transferowanych w ramach tego programu trafiła do rodzin o niższych dochodach, znajdujących się w dolnej części rozkładu dochodów. Nie można jednak wyłącznie na podstawie całkowitych korzyści rodzin w poszczególnych grupach decylowych stwierdzić, że przyczyną takiego rozkładu jest fakt wprowadzenia kryterium dochodowego na pierwsze dziecko. W tym przypadku należałoby przeanalizować także skutki zniesienia tego kryterium.

W wyniku zniesienia kryterium dochodowego w programie Rodzina 500 plus, największe wsparcie, w wysokości około 3,13 mld zł, trafi do $10 \%$ rodzin z dziećmi o najwyższych dochodach i będzie ponad 12-krotnie wyższe niż wsparcie, które trafi do $10 \%$ o najniższych dochodach. Dodatkowo w wyniku tej zmiany to właśnie grupa $10 \%$ rodzin z dziećmi o najwyższych dochodach stanie się głównym beneficjentem tego programu, a łączne wsparcie dla tej grupy wyniesie prawie 5,00 mld zł. Przykład ten jasno wskazuje, że brak kryterium dochodowego powoduje, że pomoc trafia również do osób osiągających wysokie dochody, co nie zawsze jest zgodne z celami stawianymi w ramach realizowanej polityki rodzinnej.

\section{Podsumowanie}

Z przeprowadzonej analizy wynika, że w ostatnich latach rola świadczeń pieniężnych w polskiej polityce rodzinnej znacznie wzrosła. Głównym powodem tej zmiany był wzrost wydatków na transfery skierowane do rodzin z dziećmi wynikający z wprowadzenia programu Rodzina 500 plus. Brak kryterium dochodowego w tym programie spowodował, że środki publiczne kierowane są nie tylko do rodzin najuboższych, które faktycznie mogą potrzebować wsparcia finansowego, ale trafiają również do osób o wysokich dochodach. Od momentu wprowadzenia 
w 2016 roku nowego świadczenia, udział wydatków na świadczenia rodzinne w sumie wydatków znacznie wzrósł z poziomu około 3\% w 2015 roku do około 9\% w 2017 roku, co oznacza, że wydatki na politykę rodzinną stały się ważnym elementem składowym budżetu państwa. Ze względu na wspomniane wcześniej rozszerzenie programu Rodzina 500 plus także na pierwsze dziecko, można spodziewać się dalszego wzrostu wydatków na świadczenia w budżecie państwa.

Przeprowadzone badanie pozwoliło na potwierdzenie hipotezy badawczej mówiącej o tym, że brak kryterium dochodowego upoważniającego do otrzymania świadczeń pieniężnych w ramach realizowanej polityki rodzinnej powoduje, że pomoc finansowa często trafia także do osób o wysokich dochodach. Potwierdzony został również istotny wpływ braku tego kryterium na wzrost wydatków publicznych związanych z polityką rodzinną. W związku z tym nasuwa się pytanie, czy stosowanie instrumentów bezpośredniego wsparcia, jakimi są świadczenia pieniężne bez ustalonego kryterium dochodowego, jest efektywnym rozwiązaniem i realizuje założone cele?

Problematyka podjęta w pracy dotyczyła tylko jednego z obszarów polityki rodzinnej, ale jak się okazało bardzo istotnego z punktu widzenia finansów publicznych. Wydaje się konieczne prowadzenie dalszych badań w zakresie polityki rodzinnej funkcjonującej w Polsce, która w ostatnich latach dynamicznie zmienia się, a zwłaszcza jej efektywności i kosztów.

\section{Literatura}

Auleytner J., Głąbicka K., Polityka społeczna pomiędzy opiekuńczościa a pomocniczościa, WSP TWP, Warszawa 2000.

Balcerzak-Paradowska B., Rodzina i polityka rodzinna na przełomie wieków, Instytut Pracy i Spraw Socjalnych, Warszawa, 2004.

Billingsley S., Ferrarini T., Family Policy and Fertility Intentions in 21 European Countries, „Journal of Marriage and Family” 2014, vol. 76.

Durasiewicz A., Instrumenty polityki rodzinnej państwa, [w:] Biuletyn Informacyjny Wiadomości Społeczne, nr 1/2009, K. Głąbicka (red.), Polskie Towarzystwo Polityki Społecznej, Warszawa 2009.

DurasiewiczA., Kierunki rozwoju polityki rodzinnej w Polsce - dylemat społeczny zachodzących zmian i wyzwań na przyszłość , [w:] Polityka społeczna wobec wyzwań i zmian zachodzących we współczesnym świecie, M. Kubiak (red.), Uniwersytet Gdański, Gdańsk 2014.

Kałdon B.M., Rodzina jako instytucja społeczna w ujęciu interdyscyplinarnym, „Forum Pedagogiczne UKSW" 2011, nr 1.

Kamerman S.B., Rodzina: problemy teorii i polityki, [w:] O polityce rodzinnej: definicje, zasady, praktyka, „Materiały z Zagranicy”, Instytut Pracy i Spraw Socjalnych, Warszawa 1994.

Kurzynowski A., Problemy rodziny $w$ polityce społecznej, Ośrodek Badań Społecznych, Warszawa 1991.

Informacja o realizacji ustawy o pomocy osobom uprawnionym do alimentów, MRPiPS, Warszawa, publikacje z lat 2009-2016. 
Informacja o realizacji ustawy o postępowaniu wobec dłużników alimentacyjnych oraz zaliczce alimentacyjnej, MRPiPS, Warszawa, publikacje z lat 2006-2008.

Myck M., Najsztub M., Oczkowska M., Trzciński K, Pakiet podatkowo-świadczeniowych rozwiązań rządu Zjednoczonej Prawicy, Raport Przedwyborczy CenEA, 12.04.2019 r., CenEA.

Rozporządzenie Rady Ministrów z 30 maja 2018 r. w sprawie szczegółowych warunków realizacji rządowego programu „Dobry start” (Dz.U. 2018 r., poz. 1061).

Szczepaniak-Sienniak J., Polityka rodzinna państwa we współczesnej Polsce, „Społeczeństwo i Ekonomia" 2015, nr 2(4).

Ustawa z dnia 11 lutego 2016 r. o pomocy państwa w wychowywaniu dzieci (Dz.U. z 2018 r. poz. 2134).

Ustawa z dnia 28 listopada 2003 r. o świadczeniach rodzinnych (Dz.U. z 2018 r. poz. 2220). Ustawa z dnia 7 września 2007 r. o pomocy osobom uprawnionym do alimentów (Dz.U. z 2019 r. poz. 670 ).

\section{Materiały elektroniczne:}

Adema W., Ali N., Thévenon O., Changes in Family Policies and Outcomes: Is there Convergence?, OECD Social, Employment and Migration Working Papers, 2014, no. 157, OECD Publishing, Paris, http://dx.doi.org/10.1787/5jz13wllxgzt-en [dostęp 26.06.2019].

Działania prorodzinne $w$ latach 2010-2015, GUS, Kraków, 2016, https://stat.gov.pl/ obszary-tematyczne/dzieci-i-rodzina/rodzina/dzialania-prorodzinne-w-latach-2010-2015,1,1.html [dostęp: 26.06.2019].

Lohmann H., Peter F.H., Rostgaard T., Spiess K., Towards a Framework for Assessing Family Policies in the EU, OECD Social, Employment and Migration Working Papers, 2009, no. 88, OECD Publishing, Paris, http://dx.doi.org/10.1787/223883627348 [dostęp: 26.06.2019].

Sprawozdanie z wykonania budżetu państwa, Ministerstwo Finansów, Warszawa, publikacje z lat 2006-2018, https://mf-arch2.mf.gov.pl/ministerstwo-finansow/dzialalnosc/ finanse-publiczne/budzet-panstwa/wykonanie-budzetu-panstwa/sprawozdanie-z-wykonania-budzetu-panstwa-roczne [dostęp: 26.06.2019].

Dobry start, 300 dla ucznia. Podsumowanie w 2018 r., MRPiPS, 2019, https:/ /www.gov.pl/web/ rodzina/dobry-start-to-inwestycja-w-lepsza-przyszlosc-dzieci [dostęp: 26.06.2019].

Informacja o realizacji świadczeń rodzinnych, MRPiPS, Warszawa, publikacje z lat 20062017, https://www.gov.pl/web/rodzina/informacje-statystyczne-swiadczenia-rodzinne [dostęp: 26.06.2019].

Przegląd systemów wsparcia rodzin, MRPiPS, 2017, https://www.gov.pl/web/rodzina/przeglad-systemow-wsparcia-rodzin [dostęp: 26.06.2019].

The balance of family policy tools - benefit packages, spending by age and families with young children, in Doing Better for Families, OECD Publishing, Paris 2011, https:// doi. org/10.1787/9789264098732-4-en/ [dostęp: 26.06.2019].

https:// www.portalsamorzadowy.pl/polityka-i-spoleczenstwo/500-plus-na-pierwsze-dziecko-bez-kryterium-dochodowego-ile-bedzie-kosztowac-program,121794.html [dostęp: 26.06.2019]. 